\title{
СТУДИЈЕ БИБЛИОТЕКАРСТВА И СТУДИЈЕ КУЛТУРЕ ${ }^{3}$
}

\section{Сажетак}

Представљање историјских, културних и државних тековина, како би се истакла национална самобитност, с једне, и пријатељска намера, с друге стране, даје књигама и библиотекама значајну социјалну улогу. Библиотеке, музеји, архиви, позоришта, биоскопи - активни су делатници транскултурне и међунационалне комуникације. Међусобно сусретање народа и упознавање различитих култура, ослобађање појединих нација од различитих друштвених или догматских стега, наслеђени и нови културни концепти, истицање културе као централног сегмента сопственог националног и државног идентитета уз истовремено развијање способности за разумевање и прилагођавање другим културама основи су културне флуидности и динамике културних дешавања у библиотекама, као социјално и образовно одговорним, етички кредибилним и историјски слободарски и критички профилисаним едукативним, научним, културним, рекреативним институцијама. Отуда је и наставни план Катедре за библиотекарство и информатику окренут с мером и историји библиотека, музеја и архива и новим облицима културне политике; глобалној комуникацији и културном наслеђу; проучавању континуитета језика и културе спрам друштвених криза у друштвеним медијима и библиотекама. Просперитет Катедре за библиотекарство и информатику дограђује се над чврстим темељима претходних десетлећа и усмерава ка изучавању развоја библиотека и њихове улоге у

1 Филолошки факултет, Студентски трг 3, 11000 Београд,

aleksandra.vranes@gmail.com; aleksandra.vranes@fil.bg.ac.rs

2 Овај рад је настао у оквиру пројекта бр. 178029 Министарства за просвету, науку и технолошки развој Републике Србије, Књиженство, теорија и историја женске књижевности на српском језику до 1915. године.

3 Текст раније делимично објављен: Из историје Катедре за библиотекарство и информатику Филолошког факултета Универзитета у Београду / Александра Вранеш.

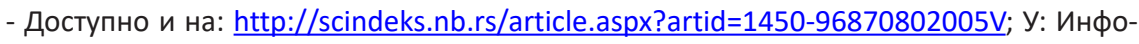
тека. - ISSN 1450-9687. - Год. 9, бр. 1/2 (2008), стр. 5-8. 
мулти-, интер- и транскултуралним технолошки напредним друштвима.

Кључне речи: Катедра за библиотекарство и информатику; Филолошки факултет Универзитета у Београду; студије библиотекарства; студије културе.

Образовање библиотекара у бившим југословенским оквирима одвијало се у Љубљани, Загребу, Сарајеву, Београду и Новом Саду (на мађарском језику). Идеја о интердисциплинарности студија развијана је на 10. скупштини Савеза друштава библиотекара Југославије 1984. године у Опатији, 11. скупштини 1986. у Охриду, Другом интеркатедарском скупу наставника библиотекарства 1986. у Загребу, Трећем интеркатедарском скупу наставника библиотекарства 1988. у Београду. Сродне катедре су и у своме самосталном развоју након 1990. године наставиле раније трасираним путем, мада су њихов даљи развој значајно обележила политичка и економска условљавања. Настале су нове катедре на универзитетима на Палама, у Вараждину, Осијеку, али се нису развиле ни у Црној Гори, ни у Македонији. Крајем 1999. године Национална библиотека Македоније покушала је да уз сарадњу са универзитетима бивше Југославије, укључујући и београдски, сачини пројекат високошколског образовања библиотекара. али у томе није успела, задржавајући професионално усавршавање на нивоу државног стручног испита.

Државни испити су пожељан и неопходан облик прове-равања знања, иако су дуго времена, од пре Другог светског рата, а ту функцију имају и данас, били облик дошколовавања кадрова. Из потребе да се библиотечки радници не едукују само на курсевима и семинарима у организацији библиотека, у Београду је 1948. године отворена трогодишња средња библиотекарска школа са 21 предметом, од којих је 6 било ужестручних. Године 1950. прерасла је у четворогодишњу и у њој је у протеклом периоду матурирала 31 генерација књижничара, који су били, а многи су и данас, понос српске библиотечке делатности. Упоредо са стручном школом у Београду радила је и школа при Радничком универзитету у Приштини од 1967. до 1976. године.

Почетком седамдесетих година, тачније 1962, у садржајима предмета на постдипломским студијама своје место добило је и библиотекарство, а од 1963. уведено је образовање библиотечког кадра од основних студија у оквиру Филолошког факултета Универзитета у 
Београду. Библиотекарство, књижарство и архивистику предавали су угледни професори Мирослав Пантић, Димитрије Вученов, Владан Недић. До 1965. године, када је Група укинута због финансијских и кадровских проблема, уписало се 25 редовних студената. Уз велико залагање и труд наставника, омогућено је да 19 студената заврши студије и дипломира, према наставном плану и програму, који је обухватао 16 предмета, од којих су пет, односно, три, били ужестручни.

Ужестручно усмеравање на средњошколском нивоу осамдесетих година обновило је образовање књижничара, а у оквиру Филолошког факултета удомило је Смер за библиотекарство као четворосеместрални програм интердисциплинарног карактера, на којем су се, током треће и четврте године студија, уз редовну наставу на матичним групама, слушала предавања из области Библиотечког пословања, Организације библиотека, Система каталога, Библиографије и научних информација и Историје књиге и библиотека, која су држали проф. др Љубица Ђорђевић, редовни професор, док су проф. др Љубинка Башовић, проф. др Војислав Максимовић, потом проф. др Десанка Стаматовић, проф. др Косара Вукасовић били наставници ангажовани из радног односа у другим установама образовања и културе. Групи су се знатно касније прикључили проф. др Владимир Јокановић, проф. др Бранко Кнежевић. Од катедарских почетака била је ту и асистент мр Александра Вранеш. Овакав облик школовања био је прихватљив и препоручљив у периоду када се једна научна дисциплина, тек почиње изучавати на универзитету. Тиме се омогућавало остваривање циклуса редовног школовања кадра за једну виталну и перспективну струку, без већих материјалних, кадровских и организационих тешкоћа, а на добрим основама ужестручне квалификације. Нестанком усмереног образовања укинута је интердисциплинарност током редовних студија, што је истовремено довело до оснивања Катедре за библиотекарство и информатику као самосталне наставно-научне јединице Филолошког факултета у Београду, која је интердисциплинарност успела да задржи на постдипломским студијама и при избору теме за докторат.

Током 1986/87. године настојало се да се установи друштвена сврсисходност за проучавање библиотекарства на универзитетском нивоу у четворогодишњем трајању студија и да се припреми Елаборат о оснивању Групе за библиотекарство. По препоруци декана Филолошког факултета проф. др Никше Стипчевића (изреченој на састанку 10. 01. 1989), упућен је позив проф. др Радославу Анђусу, 
проф. др Милану Божићу, мр Душку Витасу, доц. др Љубиши Рајићу и мр Љубомиру Жиропађи да присуствују састанку 18. 01. 19894, како би заједно са наставним кадром ондашњег Семинара за библиотекарство (доц. др Десанком Стаматовић, доц. др Косаром Вукасовић и асист. мр Александром Вранеш) испитали карактеристике сугерисаног пројекта. Састанку нису присуствовали проф. др Радослав Анђус и проф. др Милан Божић. На састанку је закључено да се прихвата предложени наставни план Групе за библиотекарство и информатику, уз следеће корекције: класификација предмета на општеобразовне, општестручне и ужестручне; стапање садржаја и назива предмета како би постојећи наставни кадар могао да изводи наставу у складу са одредбама Закона; проширење садржаја предмета Историја књиге и библиотека на технологију штампања, традиционалну и савремену; померање информатичких предмета на почетне године студија; искључивање предмета Југословенске књижевности и усклађивање програма предмета Српскохрватски језик и Примена рачунара у групе предмета. ${ }^{5}$ Чланови Катедре су као прилог записнику са ове седнице доставили наставни план, по коме су ужестручни предмети: Основи библиотекарства; Организација библиотека и библиотечко пословање, Систем каталога, Класификациони системи и индексирање, Историја књиге и библиотека са основама архивистике, Информатика и информациони системи, Библиографија и научне информације, Примена рачунара у лингвистици и науци у књижевности, Методика наставе библиотечкоинформационе делатности, Педагошка психологија; док су општестручни предмети: Енглески језик, други страни језик, Српскохрватски језик, Опште лингвистика, Социологија културе и уметности. Дискусија о Елаборату наставила се на седници одржаној 27.01.1989, којој су присуствовали, поред чланова Катедре, проф. др Недељко Парезановић, као представник Математичког факултета, саветник др Душан Витас, као представник Рачунарске лабораторије Природно-математичког факултета, и доц. др Љубиша Рајић. На предлог проф. др Недељка Парезановића прихваћено је да информатички предмети буду инкорпорирани у наставни план почев од другог семестра, како би дипломирани стручњаци били компетентни за рад у сваком рачунском центру. Уверавања др Витаса

4 Архива Катедре за библиотекарство и информатику Филолошког факултета у Београду. - Дел. бр. 299 од 19.01. 1989.

5 Исто. - Дел. бр. 301 од 28. 01. 1989. 
да би квалитет наставе био значајно побољшан уколико би Филолошки факултет потписао споразум о сарадњи са Математичким факултетом у циљу коришћења његове рачунарске учионице, отворила су и дискусију о потреби међусобног повезивања факултета са Универзитетском библиотеком «Светозар Марковић» и Народном библиотеком Србије и софтверским пакетима и базама података апликативним у библиотекарству, архивистици и лингвистици. Проф. Парезановић и др Витас преузели су на себе обавезу да обликују програме информатичке групе предмета. У акту упућеном декану Филолошког факултета, сугерисано је да наставу изводе: проф. др Недељко Парезановић за предмете Основи информатике и Примена рачунара у лингвистици; доц. др Гордана ПавловићЛажетић за предмет Информациони системи; проф. др Милан Божић за предмет Математички основи информатике. ${ }^{6}$ Елаборат о оснивању Групе за библиотекарство и информатику састојао се из три целине у којима су разматрани услови, потребе и сам програм. У време када је Елаборат процесуиран, на територији СФР библиотекарство је изучавано на филозофским факултетима у Сарајеву, Загребу, љубљани, Новом Саду (на мађарском језику). Факултету организације и информатике у Вараждину. У Семинару за библиотекарство, установљеном на Филолошком факултету у Београду 1980/81. школске године, до 1990. године наставу је похађало око 150 студената. магистрирао један и докторирало пет кандидата. Како је образовни профил дипломирани библиотекар-информатичар био дефицитаран, сматрало се да га је неопходно школовати, а проф. др Недељко Парезановић и мр Душко Витас сматрали су предложени програм „најбољим за ове студије у нашој земљи».7 Различита тумачења, правна и просветна, нису том приликом омогућила формирање Групе за библиотекарство и информатику у оквиру Семинара као организационе јединице Факултета.

Комисија за израду елабората за оснивање Катедре за библиотекарство и информатику образована је још једном на седници Савета Филолошког факултета, одржаној 11.05.1989, на којој је тим чином покренут и поступак за оснивање Катедре. Чланови Комисије били су: проф. др Мирослав Пантић (председник Комисије), проф. др Злата Бојовић, доцент др Десанка Стаматовић, мр Александра Вранеш, Јован

6 Исто. - Дел. бр. 303 од 03. 02. 1989.

7 Исто.- Дел.бр. 301 од 28.01. 1989. 
Јанићијевић и Смиља Томашевић. ${ }^{8}$ Први састанак Комисије у новом сазиву одржан је 15. 01. 1990, ${ }^{9}$ а присуствовали су му и декан проф. др Никша Стипчевић и продекан проф. др Слободан Грубачић. Мада је проф. др Мирослав Пантић изразио незадовољство због смањеног обима изучавања књижевности, истовремено је овај програм у свим другим сегментима окарактерисао као идеалан за обучавање библиотекара у општим типовима библиотека. ${ }^{10}$ Усвајањем Елабората на Универзитету, уз пуну подршку тадашњег ректора проф. др Слободана Унковића, Филолошком факултету је додељена матичност за научну област библиотекарства. Прва генерација студената библиотекарства и информатике, по усвајању елабората, уписала се на Филолошки факултет 1990. године.

Допис Катедре за библиотекарство и информатику од 12. 11. 1990. године, упућен Центру за постдипломске студије Филолошког факултета Универзитета у Београду, сведочи о даљем развијању постдипломских студија и предлогу да наставу на VII2 степену за ужестручне предмете изводе: проф. др Мирослав Пантић, проф. др Недељко Парезановић, проф. др Бранко Кнежевић, доц. др Десанка Стаматовић, мр Душан Витас (или мр Цветана Крстев). ${ }^{11}$ Настава Информатике, коју је изводио проф. Недељко Парезановић, одржавана је од 1991. године у компјутерској учионици Библиотеке града Београда12, а од 1996. године у компјутерској учионици Филолошког факултета, реализованој захваљујући донацији Данске краљевске школе из Копенхагена и Америчке амбасаде. До сада уписаних двадесет шест генерација студената, са њих око 60 у једној генерацији, потврђују потребу друштва за школовањем овако профилисаних кадрова, пораст заинтересованости младих за ову научну грану, али и научност, животност и флексибилност наставних планова и програма, јер су скоро сви дипломирани библиотекари-информатичари запослени, а нарочито позитивна околност је да су у иностранству, након нострификације дипломе, могли наставити постдипломске студије.

\footnotetext{
8 Исто. - Дел. бр. 356а од 12. 05. 1989

9 Исто.- Дел. бр. 416од 09. 01. 1990.

10 Белешке проф. др Десанке Стаматовић, седница Комисије од 15.01. 1990.

11 Архива Катедре за библиотекарство и информатику Филолошког факултета у Београду. - Дел. бр. 464 од 12. 11. 1990.

12 Исто. - Дел.бр.475а од 24. 01. 1991.
} 
Данас на Катедри за библиотекарство и информатику раде: др Гордана Стокић Симончић, ред. професор, управник Катедре; др Цветана Крстев, ред. проф; др Александра Вранеш, ред. проф. (заменик управника катедре); др Бојан Ђорђевић, ван. проф; доценти др Милош Утвић, др Драгана Грујић, др Гордана Ђоковић; секретар и библиотекар Катедре Зорица Ивковић Савић, координатор за КОБИС у факултетским библиотекама, демонстратор Марина Милошевић, сарадник у настави Анђела Стошић.

До сада уписаних двадесет шест генерација студената, са њих око 60 у једној генерацији, потврђују потребу друштва за школовањем овако профилисаних кадрова, пораст заинтересованости младих за ову научну грану, али и научност, животност и флексибилност наставних планова и програма. Поред основне групације обавезних предмета (из области: историја писма, књиге и библиотека, библиотечко пословање, организација библиотека, библиотечко законодавство, систем каталога и класификациони системи, организација знања, историјски и теоријски развој библиографије у свету и у домаћим оквирима, менаџмент и маркетинг библиотека, научне информације, информациони системи, рачунарска лингвистика, формирање и коришћење база података, архивистика, музеологија, методологија истраживања и цитирања, издаваштво и књижарство) студентима се пружа прилика да сами обликују сопствени образовни профил бирајући из групација педагошко-психолошких, филолошких, библиолошких дисциплина. Тек у новије време, због ступања на снагу прописа којима се забрањује запошљавање нових лица у државним установама, има дипломаца који нису запослени, што раније није био случај. Веома је важно што им је диплома свуда у иностранству нострификована без полагања разлика у испитима. Просперитет Катедре за библиотекарство и информатику дограђује се над чврстим темељима претходних десетлећа, у којима је студирало укупно 1384 студента (у школским: 1963/64, 1964/65, 1991/92 - 2015/16), дипломирао 521 студент (1966/67 - 1972/73, 19881/82 - 1982/83, 1994/95 - 2014/15), мастер студије завршило, по "старом програму“ 145 студената, а по „новом“, акредитованом, њих 65, док је укупно докторирало 38 кандидата.

Угледу Катедре значајно доприносе различите стручне и научне активности, као што су: успостављање сарадње са Емпориа државним универзитетом, Филозофским факултетом Универзитета „Св. Климент Охридски“ у Софији; Институтом за књигу Универзитета у Грацу; 
Институтом за међународну политику, Музејом савремене уметности у Београду); организација међународних научних конференција (Други међународни скуп наставника библиотекарства: сарадња, образовање, квалитет; Деца и библиотеке; Економска улога библиотека у савременом друштву; Лидерство у библиотекама; Интелектуална слобода у библиотекама; Етика у науци и култури; Информациона писменост и доживотно учење; Електронска библиотека; Књига и језик у развоју савременог друштва; Дигитализација културне баштине у функцији учења на даљину); организација семинара акредитованих од стране Министарства просвете (Школски библиотекар - сарадник у настави; Настава језика и књижевности у иколској библиотеци; Креативност у библиотекама); учествовање студената на пројектима под надзором наставника, какви су: обрада Дворске библиотеке, инвентарисање и ревизија у библиотекама.

Статус библиотекарства у друштву зависи од успешности обликовања образованог, активног, ефикасног, прогресивног, мотивисаног, флексибилног и приступачног библиотекара, каквог треба школовати на универзитету, а потом му омогућити да се у библиотеци развије у креативног сарадника. То му омогућава на Универзитету у Београду усвојена Болоњска декларација, захваљујући којој се поред основне групације обавезних предмета (из области: историја писма, књиге и библиотека, библиотечко пословање, организација библиотека, библиотечко законодавство, систем каталога и класификациони системи, историјски и теоријски развој библиографије у свету и у домаћим оквирима, менаџмент и маркетинг библиотека, научне информације, информациони системи, рачунарска лингвистика, формирање и коришћење база података, етика, архивистика, музеологија, издаваштво, методологија истраживања и цитирања) студентима пружа прилика да сами обликују сопствени образовни профил бирајући из групација педагошко-психолошко-методичких, филолошких, библиолошких дисциплина.

Представљање историјских, културних и државних тековина, како би се истакла национална самобитност, с једне, и пријатељска намера, с друге стране, даје књигама и библиотекама значајну социјалну улогу. Библиотеке, музеји, архиви, позоришта, биоскопи - активни су делатници транскултурне и међунационалне комуникације. Међусобно сусретање народа и упознавање различи- 
тих култура, ослобађање појединих нација од различитих друштвених или догматских стега, наслеђени и нови културни концепти, истицање културе као централног сегмента сопственог националног и државног идентитета уз истовремено развијање способности за разумевање и прилагођавање другим културама основи су културне флуидности и динамике културних дешавања у библиотекама, као социјално и образовно одговорним, етички кредибилним и историјски слободарски и критички профилисаним едукативним, научним, културним, рекреативним институцијама. Отуда је и наставни план Катедре за библиотекарство и информатику окренут с мером и историји библиотека, музеја и архива и новим облицима културне политике; глобалној комуникацији и културном наслеђу; проучавању континуитета језика и културе спрам друштвених криза у друштвеним медијима и библиотекама. Отуда се на Катедри родила идеја и Факултет ју је подржао за акредитацију мастер програма Културе у дијалогу, који у научном смислу омогућава пуну транскултуралност, мултилингвалност и интердисциплинарност, чији се развој потом подржава на докторским студијама. У практичном смислу иницијатива Катедре довела је до формирања Дигиталне библиотеке Филолошког факултета и дОИ агенције. У току су припреме за акредитацију нових студијских програма: на мастер студијама Дигитална заштита, у сарадњи са Универзитетом у Даблину и Универзитетом у Берлину, а на докторским студијама Дигитална хуманистика, у сарадњи са Емпориа универзитетом и Универзитетом у Пескари.

Наставници, сарадници и студенти Катедре за библиотекарство и информатику утичу и на виђење улоге библиотекарства и библиотечке информатике у нашем друштвеном развоју. У том смислу имају пуну сарадњу са библиотекама, музејима, архивима и другим установама културе у Србији. У њима су студенти библиотекарства и информатике радо виђени и поштовани сарадници., једнако срдачно како су колеге библиотекари драги гости, пријатељи и сарадници Филолошког факултета.

\section{Извори и литература:}

Архива Катедре за библиотекарство и информатику Филолошког факултета у Београду. The Role of University Education in Enabling Free Acess to Information / Aleksandra Vraneš 
// Journal of education for library and information science. - ISSN 0748-5786. - 48, 2 (spring 2007), p. 139-153.

Из историје Катедре за библиотекарство и информатику Филолошког факултета

Универзитета у Београду / Александра Вранеш. - Доступно и на: http:// scindeks.nb.rs/article.aspx?artid=1450-96870802005V. - У: Инфотека. - ISSN 1450-9687. - Год. 9, бр. 1/2 (2008), стр. 5-8.

\section{Prof. Aleksandra Vraneš, PhD}

\section{LIBRARY SCIENCE AND CULTURAL STUDIES}

\section{Summary}

Presentation of historical, cultural and national achievements, in order to highlight the national identity on the one hand and a friendly intention on the other attributes books and libraries an important social role. Libraries, museums, archives, theaters, cinemas - are active agents in transcultural and transnational communication. Mutual encounter of peoples and introduction to different cultures, liberation of certain nations from different social or dogmatic constraints, inherited and new cultural concepts, emphasis on culture as a central segment of national and state identity while developing skills for understanding and adapting to other cultures, are the basis of cultural fluidity and dynamics of cultural developments in libraries, as socially and educationally responsible, ethically credible,a historically libertarian and critically profiled educational, scientific, cultural and recreational institutions. Therefore, the curriculum of the Department of Library and Information Science is oriented, to a certain extent, towards both the history of libraries, museums and archives and new forms of cultural policies; global communication and cultural heritage; studies of the continuity of language and culture against social crisis in social media and libraries. The prosperity of the Department of Library and Information Science is build upon solid foundations created over the past decades and is directed towards studying the development of libraries and their role in multi-, inter- and transcultural technologically advanced societies.

Key words: Department of Library and Information Science, library science studies, cultural studies 